\title{
ENHANCING YIELD AND NUTRIENTS UTILIZATION VIA PHOSPHORIN SOIL INOCULATION AND MG FOLIAR APPLICATION TO PUMPKIN (Cucurbita moschata Duchesne) PLANTS GROWN IN SANDY CALCAREOUS SOIL Osman, A. Sh. ${ }^{1}$ and Rewaa S. El-Shatoury ${ }^{2}$ \\ ${ }^{1}$ Department of Horticulture, Faculty of Agriculture, Fayoum University, Fayoum, Egypt \\ ${ }^{2}$ Department of Horticulture, Faculty of Agriculture, Suez Canal University, Ismalia, Egypt
}

\begin{abstract}
Inoculation with phosphorien-containing phosphate-dissolving bacteria (PDB) and/or foliar application of magnesium $(\mathrm{Mg})$ at the rates of $0,0.5$ and $1 \mathrm{mM}$ on the growth, some chemical constituents and fruit yield and yield quality of pumpkin (Cucurbita moschata Duchesne) grown on a sandy calcareous soil were investigated.

Two field experiments (2012 and 2013) were performed in a completely randomized blocks design with six treatments, each with four replicates. The results indicated that PDB and/or Mg significantly increased stem length, canopy dry weight plant $^{-1}$, number of leaves plant ${ }^{-1}$, total leaf area plant ${ }^{-1}$, leaf area leaf ${ }^{-1}$, leaf contents of pigments, free proline, nitrogen $(\mathrm{N})$, phosphorus $(\mathrm{P})$, potassium $(\mathrm{K})$, magnesium $(\mathrm{Mg})$, and calcium $(\mathrm{Ca})$ and the ratio of $\mathrm{Ca} / \mathrm{Na}$, while leaf $\mathrm{Na}$ content was reduced. The application of PDB and/or Mg also increased fruit yield and yield quality (fruit length and diameter, flesh thickness, average fruit weight and fruit yield fed ${ }^{-1}$ ). It could be concluded that that PDB and Mg have pronounced positive effects on the growth, fruit yield and yield quality of pumpkin plants grown on sandy calcareous soil. PDB and $\mathrm{Mg}$, therefore, have the potential to be used as a soil inoculation and foliar application, respectively for various crops to overcome the adverse effects of the newly-reclaimed sandy calcareous soils.

Keywords: Pumpkin, Cucurbita moschata Duchesne, Bio-fertilizer, Magnesium foliar application, growth, yield, leaf chemical constituents
\end{abstract}

\section{INTRODUCTION}

Pumpkin (Cucurbita moschata Duchesne) is one of the most popular vegetable crops grown in many of the Middle Eastern countries. It is consumed in different local dishes and used for some food industries such as jams, purees and cakes. It is widely cultivated on the newly-reclaimed sandy calcareous soils, which show a great deficiency in macronutrients especially, magnesium $(\mathrm{Mg})$ and phosphorus $(\mathrm{P})$.

Mg plays a vital role in stepping up the growth and quantitative as well as qualitative features of the plant. Mg deficiency is most prevalent in sandy textured soils because it is subject to oxidation to become in a form unavailable for plant and loss by leaching (Doeing, 1986). In reclaimed sandy soils, foliar application of macro- and/or micro-nutrients are widely used and preferable (Amberger, 1982; Fawzi, 1991) and leads to significant increases in vegetative growth and productivity of some crops (Ahmed and Abd ElHameed, 2003 on red roomy vines; Osman and El-Sawah, 2009 on tomato; 
Rady and Osman, 2010on bean). $\mathrm{P}$ precipitation and immobilization is the most important problem under calcareous soil having high $\mathrm{pH}$ and calcium carbonate. Phosphorien is a bio-fertilizer product-containing PDB which hydrolyzes the insoluble phosphate into soluble one under the previous mentioned adverse conditions. Adding bio-phosphorus-fertilizers lead to significant increments in vegetative growth and productivity of some crops (Hinsinger, 2001; El-Desuki et al., 2006 on onion; Shaheen et al., 2007on onion; Rady and Osman, 2010 on bean). Therefore, the present work aims to evaluate the influence of soil inoculation with PDB (phosphorien) and/or foliar application of $\mathrm{Mg}$ on vegetative features, Fruit yield and yield quality and some chemical constituents of pumpkin (Cucurbita moschata Duchesne) grown under sandy calcareous soil conditions.

\section{MATERIALS AND METHODS}

Seed of pumpkin (cv. Balady, Fayoum Governorate) was collected from fruits characterized by: skin color; orange, flesh color; orange, fruit size; large (> $4 \mathrm{~kg}$ ), fruit shape; pyriform-globular and shell; grooved. Phosphorien (Bacillus megatherium; phosphate-dissolving bacteria) was provided by the Ministry of Agriculture and mixed with nile water to obtain the concentration of about $0.25 \times 10^{7} \mathrm{cfu} \mathrm{ml}^{-1}$, and $\mathrm{Mg}$ concentrations used were $0,0.5$ and $1 \mathrm{mM}$ combined with or without phosphorien (6 treatments in total). The rates of $\mathrm{Mg}$ ( 0.5 and $1 \mathrm{mM}$ ) were selected based on our preliminary studies, since these rates were generated the best responses. A two-field experiment was undertaken at the Experimental Farm, Faculty of Agriculture, Fayoum University, Egypt in 2012 and 2013 seasons. Preceding the initiation of experiment, soil samples to $25 \mathrm{~cm}$ depth were collected and analyzed. Some of the chemical and physical properties according to the standard procedures of Wilde et al. (1985) are presented in Table 1.

Table1: Physical and chemical properties of the experimental soil before planting in 2012 and 2013 seasons

\begin{tabular}{|c|c|c|}
\hline Parameter & 2012 & 2013 \\
\hline Clay [\% (w/w)] & 22.7 & 23.8 \\
\hline Silt $[\%(w / w)]$ & 23.1 & 22.1 \\
\hline Sand $[\%(w / w)]$ & 54.2 & 54.1 \\
\hline Soil texture & sandy & Sandy \\
\hline $\mathrm{pH}(1: 2.5)$ & 8.11 & 7.86 \\
\hline $\operatorname{ECe}\left(\mathrm{dS} \mathrm{m}^{-1}\right)$ & 5.10 & 4.85 \\
\hline Organic matter $[\%(\mathrm{w} / \mathrm{w})]$ & 1.17 & 1.24 \\
\hline $\mathrm{CaCO}_{3}[\%(\mathrm{w} / \mathrm{w})]$ & 14.05 & 14.32 \\
\hline Available $\mathrm{N}\left(\mathrm{mg} \mathrm{kg}^{-1} \mathrm{DW}\right)$ & 43.31 & 42.00 \\
\hline Available $\mathrm{P}\left(\mathrm{mg} \mathrm{kg}^{-1} \mathrm{DW}\right)$ & 8.11 & 9.15 \\
\hline Available $\mathrm{K}\left(\mathrm{mg} \mathrm{kg}^{-1} \mathrm{DW}\right)$ & 73.16 & 74.43 \\
\hline Available $\mathrm{Fe}\left(\mathrm{mg} \mathrm{kg}^{-1} \mathrm{DW}\right)$ & 7.03 & 8.01 \\
\hline Available $\mathrm{Mn}\left(\mathrm{mg} \mathrm{kg}^{-1} \mathrm{DW}\right)$ & 4.52 & 5.32 \\
\hline Available $\mathrm{Zn}\left(\mathrm{mg} \mathrm{kg}^{-1} \mathrm{DW}\right)$ & 2.24 & 2.43 \\
\hline Available $\mathrm{Cu}\left(\mathrm{mg} \mathrm{kg}^{-1} \mathrm{DW}\right)$ & 0.45 & 0.43 \\
\hline
\end{tabular}


During preparation of the experimental site, farmyard manure at the rate of $15 \mathrm{~m}^{3}, 150 \mathrm{~kg}$ calcium superphosphate $\left(15.5 \% \mathrm{P}_{2} \mathrm{O}_{5}\right)$ and $100 \mathrm{~kg}$ elemental sulphur $\mathrm{fed}^{-1}$ were broadcasted and incorporated in the soil. Pumpkin seeds were sown on 11 and 20 March in 2012 and 2013, respectively.

Soil inoculation with phosphorien was performed by injecting $35 \pm 5 \mathrm{ml}$ hole $^{-1}$ two times; 20 and 40 days after sowing at the rhizosphere area. The respective source of $\mathrm{Mg}$ was Librel $5.5 \% \mathrm{Mg}$ in chelated form (EDTA, Ciba Specialty chemicals, United Kingdom). Mg solutions were foliar sprayed to run off two times; 25 and 40 days after sowing. Few drops of Tween-20 were added to the spraying solution as a wetting agent. The experimental design was completely randomized blocks with 6 treatments, each with 4 replicates. Each experimental unit measured $80 \mathrm{~m}^{2}$ and consisted of 5 rows; $8 \mathrm{~m}$ long and $2 \mathrm{~m}$ width, with row spacing averaged $50 \mathrm{~cm}$ apart. Each two adjacent experimental unites were separated by $1 \mathrm{~m}$ alley.

After complete earthing, a seasonal total of 66 and $48 \mathrm{~kg} \mathrm{~N}$ and $\mathrm{K}_{2} \mathrm{O}$ in the form of ammonium nitrate $(33.5 \% \mathrm{~N})$ and potassium sulphate $\left(48 \% \mathrm{~K}_{2} \mathrm{O}\right)$, respectively were applied in two equal applications; 30 and 60 days after sowing, respectively. All other agro-management practices for commercial production of pumpkin were followed whenever it was necessary.

Measurements of growth traits

Fifty-five days after sowing, five plants were randomly chosen from the two outer rows of each experimental unit and cut off at ground level to measure the stem length, canopy dry weight plant ${ }^{-1}$, number of leaves plant ${ }^{-1}$ using a digital LI-3000 Portable area meter (LI-COR Lincoln, Nebraska, USA), total leaf area plant ${ }^{-1}$ and leaf area leaf ${ }^{-1}$ was calculated using the following formula:

$$
\text { Leaf area leaf }^{-1}=\frac{\text { Leaves area plant }^{-1}}{\text { Number of leaves plant }^{-1}}
$$

\section{Measurements of fruit yield and yield quality}

In each experimental unit after 115 days from sowing plants of the three middle rows were left to grow till the fruits approach the marketable stage. Then, fruits were picked from 20 plants to determine average fruit weight $(\mathrm{kg})$, fruit length $(\mathrm{cm})$ for the longitudinal axis starting from the peduncle junction to the blossom end, fruit diameter $(\mathrm{cm})$ at the maximum fruit diameter, flesh thickness of fruit $(\mathrm{cm})$, average of four measures, at the beginning of the fruit cavity, at the maximum fruit diameter, and at the blossom end, flesh samples were taken from four different parts of fruit and percent of total soluble solids (TSS\%) were measured using a hand heldle refractometer (HRN- 32, Kruss, Germany). The total yield of fruit fed ${ }^{-1}$ was calculated from all plants of the three middle rows.

Leaf photosynthetic pigment, proline and nutrient determinations

Leaf samples were collected from the fourth upper leaf of five randomly selected plants from each experimental unit, after 60 days from planting, to 
determine the concentrations of some nutrients. Leaf chlorophyll and carotenoid contents in the $4^{\text {th }}$ leaf were colorimetrically determined as outlined by Arnon (1949). Leaf samples were dried in a forced air oven at 70 ${ }^{\circ} \mathrm{C}$ till a constant weight and then ground. For leaf mineral determinations, samples of fine dry ground material each of $0.1 \mathrm{~g}$ was digested with a mixture of sulphuric and perchloric acids as mentioned by Piper (1947). Free proline ( $\mu \mathrm{g} \mathrm{g}^{-1}$ leaf dry matter) was extracted by 5 -sulphosalicylic acid $(3 \%)$ then, determined colorimetrically using acid ninhydrin reagent as outlined by Bates et al. (1973). Leaf $\mathrm{N}$ content was colorimetrically determined using Orange $\mathrm{G}$ dye as suggested by Hafez and Mikkelsen (1981). Leaf P content was colorimetrically estimated using the method of chloro-stannus molybdophosphoric blue color in sulphuric acid system according to the procedure of Jackson (1967). Leaf $\mathrm{K}$ and $\mathrm{Na}$ contents were determined using a Flamephotometer as documented by Page et al. (1982). Leaf $\mathrm{Ca}$ and $\mathrm{Mg}$ contents were measured using a Perkin-Elmer, Model 3300, Atomic Absorption Spectrophotometer as mentioned by Chapman and Pratt (1961).

\section{Statistical analysis}

Data of the two seasons were subjected to the statistical analysis according to the design used (Snedecor and Cochran, 1980). All data were statistically analyzed based on ANOVA and Duncan Multiple Range Test of means by using Co-stat statistical software (V. 6.311).

\section{Vegetative Growth Traits}

\section{RESULTS AND DISCUSSION}

Data in Table 2 show that stem length, canopy dry weight plant ${ }^{-1}$, number of leaves plant ${ }^{-1}$, total leaf area plant $^{-1}$ and leaf area leaf ${ }^{-1}$ significantly increased in plants that foliar sprayed with $\mathrm{Mg}$ at the 2 rates $(0.5$ and $1 \mathrm{mM})$ compared to plants that not treated with $\mathrm{Mg}$. Plants received $\mathrm{Mg}$ at the rate of $1 \mathrm{mM}$ gave higher growth traits than plants received $\mathrm{Mg}$ at $0.5 \mathrm{mM} \mathrm{Mg}$. Soil inoculation with phosphorien further increased growth traits. The best results were obtained from the combined treatment of soil inoculation with biophosphorus fertilizer and foliar application with $1 \mathrm{mM} \mathrm{Mg}$. The same trend was observed over both the 2012 and 2013 growing seasons.

These results can be explained on the basis that, phosphate-solublizing bacteria produces organic and inorganic acids and/or $\mathrm{CO}_{2}$ which dissolve the precipitated form of phosphate to an available one. Thereby, offered adequate quantity of phosphorus in root media, promotes roots growth to go forward and keep roots healthy (Zayed, 1998; Rady and Osman, 2010). Phosphate-solubilizing bacteria also produses many growth-promoting substances such as auxins, gibberellins and cytokinins (Sabik et al., 2001), these substances improve plant growth and stimulate beneficial microbial development in the rhizosphere zone (Abdel-Rasoul et al., 2002). Many investigators reported similar findings on broad bean (Hinsinger, 2001), on onion (Shafeek et al., 2004; Shaheen et al., 2007), on garlic (Badawy et al., 2008) and on bean (Rady and Osman, 2010).

Addition of $\mathrm{Mg}$ as foliar application is ready to be absorbed through leaves and not to be lost through fixation, decomposition or leaching under unfavorable soil conditions. $\mathrm{Mg}$ is essential component of chlorophyll 
molecule and plays a vital role in carbohydrate synthesis due to activation of many enzymes (Marschner, 1995). He also stated that Mg acts as an osmotic material in the cells against adverse conditions and consequently the metabolic activities are completely achieved due to the cell turgor. Hao and Papadoulos (2004) on tomato, Rady and Osman (2010) on bean, stated that plant dry matter production increased as $\mathrm{Mg}$ concentration increased to a certain level. These results are in accordance with those obtained by Ahmed and Abd El-Hameed (2003) and Osman and El-Sawah (2009).

Table 2: Effect of soil inoculation with phosphorien (Bio-P) and foliar application with magnesium (Mg; $\mathrm{mM}$ ) on vegetative growth traits of pumpkin plants (at 55 days from sowing) grown in 2012 and 2013 seasons

\begin{tabular}{|c|c|c|c|c|c|c|}
\hline \multicolumn{2}{|c|}{ Treatment } & \multirow{2}{*}{$\begin{array}{l}\text { Stem } \\
\text { length } \\
(\mathrm{cm})\end{array}$} & \multirow{2}{*}{$\begin{array}{c}\text { Canopy } \\
\text { DW } \\
\left(\text { g plant }^{-1}\right)\end{array}$} & \multirow{2}{*}{$\begin{array}{l}\text { No. of } \\
\text { leaves } \\
\left.\text { (plant }^{-1}\right)\end{array}$} & \multirow{2}{*}{$\begin{array}{c}\text { Leaf area } \\
\text { leaf }^{-1} \\
\left(\mathrm{dm}^{2} \text { leaf }^{-1}\right)\end{array}$} & \multirow{2}{*}{$\begin{array}{c}\text { Leaf area } \\
\text { plant }^{-1} \\
\left(\mathrm{dm}^{2} \text { plant }^{-1}\right)\end{array}$} \\
\hline Bio-P & $\mathrm{Mg}(\mathrm{mM})$ & & & & & \\
\hline & & & & 2012 season & & \\
\hline & 0 & $174 d^{*}$ & $96 d$ & $36 d$ & $2.34 d$ & $84.4 \mathrm{c}$ \\
\hline \multirow[t]{3}{*}{ without } & 0.5 & $193 c$ & $119 c$ & $43 c$ & $2.56 \mathrm{c}$ & $110.2 c$ \\
\hline & 1 & $220 b$ & $131 b$ & $51 b$ & $2.84 b$ & $144.6 b$ \\
\hline & 0 & $185 c d$ & $113 c$ & $41 \mathrm{~cd}$ & $2.64 c$ & $108.1 c$ \\
\hline \multirow[t]{3}{*}{ With } & 0.5 & $225 b$ & $134 b$ & $53 a b$ & $2.90 \mathrm{~b}$ & $153.4 b$ \\
\hline & 1 & $268 a$ & $153 a$ & 58 a & $3.19 a$ & $185.1 \mathrm{a}$ \\
\hline & 0 & $183 d$ & $104 d$ & $41 d$ & $2.42 d$ & $99.3 c$ \\
\hline \multirow[t]{3}{*}{ without } & 0.5 & $203 c$ & $122 c$ & $48 c$ & $2.69 c$ & $129.2 \mathrm{c}$ \\
\hline & 1 & $231 b$ & $139 b$ & $54 b$ & $2.90 \mathrm{~b}$ & $156.4 \mathrm{~b}$ \\
\hline & 0 & $196 c$ & $121 \mathrm{c}$ & $44 \mathrm{~cd}$ & $2.72 c$ & $119.5 c$ \\
\hline \multirow[t]{2}{*}{ With } & 0.5 & $240 b$ & $145 b$ & $57 a b$ & $2.96 b$ & 168.3ab \\
\hline & 1 & $276 a$ & $169 a$ & $62 a$ & $3.23 a$ & $199.8 a$ \\
\hline
\end{tabular}

Likewise, the comparisons within soil inoculation with and without phosphorien reflect the valuable effect of soil inoculation with phosphorien and spraying $\mathrm{Mg}$, particularly at $1 \mathrm{mM}$, on all various studied vegetative parameters compared to the untreated control. Therefore, the best valuable combination was soil inoculation with phosphrien and foliar application of $\mathrm{Mg}$ at $1 \mathrm{mM}$. The superiority of the combined treatment having the highest results might have come from improving the nutritional status of plants of this treatment (Table 4), the abundant values of leaf pigments (Table 3), the obvious shortage in $\mathrm{Na}^{+}$(Table 4) saving more osmotic solutes which enable plant cells to maintain more water against the adverse conditions of the soil under study.

Leaf photosynthetic pigment, free praline and nutrient contents

Data in Tables 3 and 4 reveal that the contents of total chlorophyll, total carotenoids, free proline, $\mathrm{N}, \mathrm{P}, \mathrm{K}, \mathrm{Mg}$ and $\mathrm{Ca}$, and the ratio of $\mathrm{Ca} / \mathrm{Na}$ significantly increased in plants, which received 0.5 or $1 \mathrm{mM} \mathrm{Mg}$ as foliar application compared to those untreated ones. Plants supplied with $\mathrm{Mg}$ at the rate of $1 \mathrm{mM}$ had higher total chlorophyll, total carotenoids, free proline and nutrient contents and $\mathrm{Ca} / \mathrm{Na}$ ratio than plants applied with $\mathrm{Mg}$ at $0.5 \mathrm{mM} \mathrm{Mg}$. 
Further increased contents of these attributes were observed with soil inoculation with phosphorien. The content of $\mathrm{Na}$ showed the reverse trend to other measurements. The best results were obtained from the combined treatment of soil inoculation with phosphorien and foliar application with $1 \mathrm{mM}$ Mg. Similar trends were observed in both the 2012 and 2013 growing seasons.

The enhancing effects of phosphorien on the contents of leaf nutrients and photosynthetic pigments can be owe to the efficiency of phosphorien in dissolving immobilized $\mathrm{P}$ and producing appropriate amounts of phytohormones, which increased surface area per unit area of root with an eventual increase in the uptake of nutrients from the soil. Therefore, more storage of energy in the form of ADP and ATP which grant transportation of nutrient across the cell wall and the synthesis of nucleic acid and proteins as well as other photosynthates. These results are in accordance with those of Al-kaff et al. (2002), Badawy et al. (2008), Rady and Osman (2010) and Naeem et al. (2010).

The positive linear relationship between foliar application of $\mathrm{Mg}$ and leaf $\mathrm{Mg}$ content and interrelationship between leaf $\mathrm{Mg}$ and $\mathrm{P}$ contents due to $\mathrm{Mg}$ acts as a carrier of $\mathrm{P}$ in plants were documented by Osman and El-Sawah (2009) and Rady and Osman (2010). Marschner (1995) stated that Mg is essential element involving in the biosynthesis of chlorophyll and consequently the higher leaf $\mathrm{Mg}$ content, and consequently the higher leaf chlorophyll content. The combined treatment of soil inoculation with phosphorien plus foliar application of $\mathrm{Mg}$ at $1 \mathrm{mM}$ significantly attained the highest leaf chlorophyll, carotenoid, N, P, K, Mg and Ca contents.

Table 3: Effect of soil inoculation with phosphorien (Bio-P) and foliar application with magnesium ( $\mathrm{Mg}$; $\mathrm{mM}$ ) on the leaf contents of photosynthetic pigments and free proline $\left(\mu \mathrm{g} \mathrm{g}^{-1} \mathrm{DW}\right)$ of pumpkin plants (at 60 days from sowing) grown in 2012 and 2013 seasons

\begin{tabular}{|c|c|c|c|c|}
\hline Bio-P & $\begin{array}{l}\text { ment } \\
M g(m M)\end{array}$ & $\begin{array}{l}\text { Total chlorophyll } \\
\left.\text { (mg g } \text { }^{-1} \mathrm{FW}\right)\end{array}$ & $\begin{array}{l}\text { Total carotenoids } \\
\left.\text { ( } \mathrm{mg} \mathrm{g}^{-1} \mathrm{FW}\right)\end{array}$ & $\begin{array}{l}\text { Free proline } \\
\left(\mu \mathrm{g} \mathrm{g}^{-1} \mathrm{DW}\right)\end{array}$ \\
\hline \multirow{4}{*}{ without } & & & 2012 & \\
\hline & 0 & $0.89 \mathrm{~d}^{\times}$ & $0.33 d$ & $24.3 \mathrm{c}$ \\
\hline & 0.5 & $1.09 \mathrm{c}$ & $0.39 \mathrm{c}$ & $26.7 \mathrm{~b}$ \\
\hline & 1 & $1.26 \mathrm{~b}$ & $0.50 \mathrm{~b}$ & $28.1 \mathrm{~b}$ \\
\hline \multirow{4}{*}{ with } & 0 & $1.00 \mathrm{c}$ & $0.43 \mathrm{c}$ & $27.7 \mathrm{~b}$ \\
\hline & 0.5 & $1.29 \mathrm{~b}$ & $0.52 \mathrm{~b}$ & $31.2 a$ \\
\hline & 1 & $1.38 a$ & $0.58 a$ & $32.3 a$ \\
\hline & & & 2013 & \\
\hline \multirow{3}{*}{ without } & 0 & $0.93 d$ & $0.36 \mathrm{~d}$ & $26.5 \mathrm{c}$ \\
\hline & 0.5 & $1.12 \mathrm{c}$ & $0.45 \mathrm{c}$ & $28.4 \mathrm{bc}$ \\
\hline & 1 & $1.29 \mathrm{~b}$ & $0.53 b$ & $30.1 \mathrm{~b}$ \\
\hline \multirow{3}{*}{ with } & 0 & $1.05 \mathrm{c}$ & $0.46 \mathrm{c}$ & $29.1 \mathrm{~b}$ \\
\hline & 0.5 & $1.32 \mathrm{~b}$ & $0.55 \mathrm{~b}$ & $32.8 a$ \\
\hline & 1 & $1.44 a$ & $0.63 a$ & $33.7 a$ \\
\hline
\end{tabular}


Table 4: Effect of soil inoculation with phosphorien (Bio-P) and foliar application with magnesium ( $\mathrm{Mg}$; $\mathrm{mM}$ ) on leaf mineral content and the ratio of $\mathrm{Ca} / \mathrm{Na}$ of pumpkin plants (at 60 days from sowing) grown in 2012 and 2013 seasons

\begin{tabular}{|c|c|c|c|c|c|c|c|c|}
\hline \multicolumn{2}{|c|}{ Treatment } & \multirow{2}{*}{$\begin{array}{c}\mathrm{N} \\
\left(\mathrm{mg} \mathrm{g}^{-1}\right. \\
\mathrm{DW})\end{array}$} & \multirow{2}{*}{$\begin{array}{c}P \\
\left(\mathrm{mg} \mathrm{g}^{-1}\right. \\
\text { DW) }\end{array}$} & \multirow{2}{*}{$\begin{array}{c}\mathrm{K} \\
\left(\mathrm{mg} \mathrm{g}^{-1}\right. \\
\text { DW) }\end{array}$} & \multirow{2}{*}{$\begin{array}{c}\mathrm{Mg} \\
\left(\mathrm{mg} \mathrm{g}^{-1}\right. \\
\text { DW })\end{array}$} & \multirow{2}{*}{$\begin{array}{c}\mathrm{Na} \\
\left(\mathrm{mg} \mathrm{g}^{-1}\right. \\
\mathrm{DW})\end{array}$} & \multirow{2}{*}{$\begin{array}{c}\mathrm{Ca} \\
\left(\mathrm{mg} \mathrm{g}^{-1}\right. \\
\mathrm{DW})\end{array}$} & \multirow{2}{*}{$\begin{array}{c}\mathrm{Ca} / \mathrm{Na} \\
\text { ratio }\end{array}$} \\
\hline Bio-P & $M g(m M)$ & & & & & & & \\
\hline & & & & & 2012 & & & \\
\hline & 0 & $18.2 d^{*}$ & $2.67 d$ & $24.2 d$ & $1.48 \mathrm{e}$ & $6.23 a$ & $2.30 \mathrm{c}$ & $0.37 \mathrm{c}$ \\
\hline \multirow[t]{3}{*}{ without } & 0.5 & $20.9 c$ & $3.15 c$ & $26.8 \mathrm{~cd}$ & $1.80 \mathrm{~d}$ & 5.89ab & $2.64 b$ & $0.45 b c$ \\
\hline & 1 & $24.4 b$ & $3.41 \mathrm{c}$ & $28.4 \mathrm{bc}$ & $2.09 c$ & $5.50 \mathrm{bc}$ & $2.85 \mathrm{~b}$ & $0.52 b$ \\
\hline & 0 & $21.2 c$ & $3.27 c$ & $28.6 \mathrm{bc}$ & $2.01 \mathrm{c}$ & $5.26 \mathrm{~cd}$ & $2.72 b$ & $0.52 b$ \\
\hline \multirow[t]{3}{*}{ with } & 0.5 & $25.2 b$ & $4.03 b$ & $30.2 a b$ & $2.51 \mathrm{~b}$ & $4.82 \mathrm{de}$ & $3.21 \mathrm{a}$ & $0.67 a$ \\
\hline & 1 & $28.3 a$ & $4.65 a$ & $31.3 a$ & $\begin{array}{r}2.97 a \\
2013\end{array}$ & $4.58 \mathrm{e}$ & $3.38 a$ & $0.74 a$ \\
\hline & 0 & $18.8 d$ & $2.82 d$ & $24.8 d$ & $1.53 \mathrm{e}$ & $6.07 a$ & $2.46 c$ & $0.41 \mathrm{c}$ \\
\hline \multirow[t]{3}{*}{ without } & 0.5 & $21.6 c$ & $3.26 c$ & $27.5 c$ & $1.86 \mathrm{~d}$ & 5.73ab & $2.86 \mathrm{~b}$ & $0.50 \mathrm{bc}$ \\
\hline & 1 & $25.1 b$ & $3.73 c$ & $29.1 b$ & $2.15 c$ & $5.35 \mathrm{bc}$ & $3.01 \mathrm{~b}$ & $0.56 b$ \\
\hline & 0 & $21.7 c$ & $3.46 c$ & $29.3 b$ & $2.08 c$ & $5.13 c$ & $2.91 \mathrm{~b}$ & $0.57 \mathrm{~b}$ \\
\hline \multirow[t]{2}{*}{ with } & 0.5 & $26.2 b$ & $4.22 b$ & $32.5 a$ & $2.59 \mathrm{~b}$ & $4.62 d$ & $3.30 a$ & $0.71 \mathrm{a}$ \\
\hline & 1 & $29.4 a$ & $4.78 a$ & $33.6 a$ & $3.05 a$ & $4.48 d$ & $3.41 \mathrm{a}$ & $0.76 a$ \\
\hline
\end{tabular}

Fruit yield and yield quality

Data in Table 5 show that, except TSS in the first season, the fruit yield and yield quality (fruit length and diameter, flesh thickness, average fruit weight and fruit yield $\mathrm{fed}^{-1}$ ) significantly increased with plants which sprayed with $\mathrm{Mg}$ at the 2 rates $(0.5$ and $1 \mathrm{mM})$ compared to plants that not supplied with $\mathrm{Mg}$. Plants received $\mathrm{Mg}$ at the rate of $1 \mathrm{mM}$ gave higher fruit yield than plants received $\mathrm{Mg}$ at $0.5 \mathrm{mM} \mathrm{Mg}$. Soil inoculation with phosphorien further increased fruit yield. The best results were obtained when the combined treatment of soil inoculation with bio-phosphorus fertilizer and foliar application with $1 \mathrm{mM} \mathrm{Mg}$ was applied. The same trends were seen in both the 2012 and 2013 growing seasons.

The enhancing effects of soil inoculation with phosphorien on fruit length and diameter, flesh thickness, average fruit weight and fruit yield fed ${ }^{-1}$ can be attributed to the positive effects of phosphorien on plant growth traits (Table 2 ) and leaf photosynthetic pigment contents (Table 3), which may coubled togther to enhance photosynthesis to go forward. Also, phosphorien-treated soil improved plant nutritional status (Table 4) and probably reflected better partitioning of photosynthates to reproductive organs with an eventual result increasing fruit yield and yield quality. Many investigators reported similar trends on onion (El-Desuki et al., 2006; Shaheen et al., 2007), on garlic (Badawy et al., 2008) and on bean (Rady and Osman, 2010). 
Table 5: Effect of soil inoculation with phosphorien (Bio-P) and foliar application with magnesium (Mg; $\mathrm{mM}$ ) on yield and fruit quality of pumpkin plants grown in 2012 and 2013 seasons

\begin{tabular}{|c|c|c|c|c|c|c|c|}
\hline \multicolumn{2}{|c|}{ Treatment } & \multirow{2}{*}{$\begin{array}{l}\text { Fruit } \\
\text { length } \\
\text { (cm) }\end{array}$} & \multirow{2}{*}{$\begin{array}{c}\text { Fruit } \\
\text { diameter } \\
\text { (cm) }\end{array}$} & \multirow{2}{*}{$\begin{array}{c}\text { Flesh } \\
\text { thickness } \\
\text { (cm) }\end{array}$} & \multirow{2}{*}{$\begin{array}{l}\text { TSS } \\
\text { (\%) }\end{array}$} & \multirow{2}{*}{$\begin{array}{c}\text { Average } \\
\text { fruit weight } \\
(\mathrm{kg})\end{array}$} & \multirow{2}{*}{$\begin{array}{l}\text { Fruit yield } \\
\text { fed }^{-1} \\
\text { (ton fed }^{-1} \text { ) }\end{array}$} \\
\hline Bio-P & $M g(m M)$ & & & & & & \\
\hline & & \multicolumn{6}{|c|}{2012} \\
\hline & 0 & $17.6 d^{*}$ & $12.2 d$ & $3.0 \mathrm{~d}$ & $5.98 a$ & $3.11 d$ & $15.0 d$ \\
\hline \multirow[t]{3}{*}{ without } & 0.5 & $19.7 c$ & $14.3 c$ & $3.3 \mathrm{~cd}$ & $5.93 a$ & $3.42 \mathrm{c}$ & $16.9 c$ \\
\hline & 1 & $22.5 b$ & $16.1 \mathrm{~b}$ & $3.7 \mathrm{~b}$ & $5.89 a$ & $3.66 \mathrm{~b}$ & $18.4 b$ \\
\hline & 0 & $19.5 c$ & $14.6 c$ & $3.3 \mathrm{~cd}$ & $6.02 a$ & $3.52 \mathrm{c}$ & $17.5 c$ \\
\hline \multirow[t]{4}{*}{ with } & 0.5 & $23.1 \mathrm{~b}$ & 16.7ab & $4.0 \mathrm{ab}$ & $6.01 \mathrm{a}$ & $3.76 \mathrm{~b}$ & $18.8 b$ \\
\hline & 1 & $25.5 a$ & $17.2 a$ & $4.3 a$ & $5.93 a$ & $3.93 a$ & $20.7 a$ \\
\hline & & \multicolumn{6}{|c|}{2013} \\
\hline & 0 & $18.4 d$ & $12.7 e$ & $2.9 d$ & $6.03 a$ & $3.40 \mathrm{~d}$ & $16.7 d$ \\
\hline \multirow[t]{3}{*}{ without } & 0.5 & $20.4 c$ & $14.9 d$ & $3.3 \mathrm{~cd}$ & $6.01 \mathrm{a}$ & $3.74 \mathrm{c}$ & $18.6 c$ \\
\hline & 1 & $23.1 b$ & $16.5 b c$ & $3.5 b c$ & $5.98 b$ & $4.00 \mathrm{~b}$ & $20.2 b$ \\
\hline & 0 & $20.6 c$ & $15.0 \mathrm{c}$ & $3.3 \mathrm{~cd}$ & $6.03 a$ & $3.81 \mathrm{c}$ & $18.9 c$ \\
\hline \multirow[t]{2}{*}{ with } & 0.5 & $23.8 b$ & 17.1ab & $3.9 a b$ & $6.04 a$ & $4.11 \mathrm{~b}$ & $20.7 b$ \\
\hline & 1 & $26.1 \mathrm{a}$ & $17.9 a$ & $4.2 \mathrm{a}$ & $6.01 \mathrm{a}$ & $4.34 a$ & $22.7 a$ \\
\hline
\end{tabular}

The improving effects of $\mathrm{Mg}$ on studied yield and yield quality was mainly attributed to its positive action on enhancing vegetative growth traits (Table 2), leaf photosynthetic pigments (Table 3 ) and plant nutritional status (Table 4) for sustenance of cells turgor leading to maintenance of metabolic activities in plants at their highest levels. In this respect, on different crops, Ahmed and Abd El-Hameed (2003), Hao and Papadoulos (2004), Osman and El-Sawah (2009) and Rady and Osman (2010) found a positive relationship between yield and $\mathrm{Mg}$ level which may attributed to the important role of $\mathrm{Mg}$ in increasing the activity of plant metabolism, which in turn reflected on the yield under study. At any concentration of $\mathrm{Mg}$, soil application of phophorien was pioneer and recorded higher mean values of all studied parameters of fruit yield and yield quality than the un-inoculated ones. Likely, soil inoculation with phosphorien reflects the desirable effect of $\mathrm{Mg}$ on all studied parameters of fruit yield and yield quality, particularly at $1 \mathrm{mM}$. The superiority of the best combined treatment on fruit yield and yield quality may be arised as a result of positive combined effects of soil inoculation with phosphate-solubilizing bacteria and foliar application with $1 \mathrm{mM} \mathrm{Mg}$ on growth traits (Table 2), leaf photosynthetic pigments (Table 3 ) and nutritional status of plants (Tables 4).

We concluded that, under the conditions of sandy calcareous soils, phosphorien (phosphate-solubilizing bacteria) was capable to hydrolyze the insoluble phosphate into soluble one, which reflected an increase of $\mathrm{Mg}$ foliar application efficiency in overcoming the great deficiency of Mg in such soils. Therefore, the positive reflection of these applications on growth, fruit yield and chemical composition of pumpkin (cv. Balady, Fayoum Governorate) was expected. 


\section{REFERENCES}

Abdel-Rasoul, Sh.M., El-Banna, A.A., Abd El-Moniem, M.M., Amer, A.A., 2002. Bio and organic fertilization for peanut plant grown on new reclaimed sandy soil. Egypt. J. Appl. Sci. 17: 127-142.

Ahmed, A.M. and Abd El-Hameed, H.M., 2003. Growth, uptake of some nutrients and productivity of red roomy vines as affected by spraying of some amino acids, magnesium and boron. Minia J. Agric. Res. Dev. 23: 649-666.

Al-Kaff, H.A., Saeed, O.S., Salm, A.Z., 2002. Effect of biofertilizer, inorganic, organic and foliar application of Power 4 on the productivity of onion (Arabic). J. Natural and Applied Sci., Univ. of Aden, Aden, Yemen, 6 (1): $1-14$.

Amberger, A., 1982. Micronutrient and other iron problems in Egypt. Short Communication. J. Plant Nutr. 5: 967-971.

Arnon, D.I., 1949. Copper enzymes in isolated chloroplasts. Polyphenoloxidase in Beta vulgaris L. Plant Physiol. 24: 1-5.

Badawy, A.S., Hosseny, M.H., Mohamed, H.E., 2008. Effect of bio- and chemical phosphate fertilization on growth, yield and quality of garlic (Allium sativum L.) grown in new reclaimed soil. The $4^{\text {th }}$ Conf. Sustain. Agric. Dev., Fac. Agric., Fayoum Univ., 20-22 Oct., pp. 231-242.

Bates, L.S., Waldren, R.P., Teare, I.D., 1973. Rapid determination of free proline for water stress studies. Plant and Soil, 39: 205-207.

Chapman, H.D., Pratt, P.F., 1961. Methods of Analysis for Soil, Plant and Water. Univ. Calif., D. V., Agric. Sci., USA.

Doeing, H.W., 1986. Foliar fertilization. An effect method for controlling micronutrients deficiencies on calcareous and saline soil in arid lands. In: Proc. Symp. Application of Special Fertilizers. Alex. 21-23 Feb., Egypt (Ed.) El-Fouly, M.M. Ribner and H4hr, G., p 23.

El-Desuki, M., Mahmoud, A.R., Hafiz, M.M., 2006. Response of onion plants to mineral and bio-fertilizers application. Res. J. Agric. and Biol. Sci. 2: 292-298.

Fawzi, A.F.A., 1991. Micronutrients effects on field crops in Egypt. Proc. $4^{\text {th }}$ Micronutrients Workshop, Amman, Jordan, pp 5-30.

Hafez, A.R., Mikkelsen, D.S., 1981. Colorimetric determination of nitrogen for evaluating the nutritional status of rice. Commun. Soil Sci. and Plant Analysis, 12: 61-69.

Hao, X. and Papadoulos, A.P., 2004. Effect of calcium and magnesium on plant growth, biomass partitioning and fruit yield of winter greenhouse tomato. HortScience, 39: 512-515.

Hinsinger, $P$., 2001. Bioavailability of soil inorganic $P$ in the rhizosphere as affected by root-induced chemical changes: A Review Plant and Soil 237: 173-195.

Jackson, M.L., 1967. Soil Chemical Analysis. Prentice-Hall of India Private Limited, New Delhi, pp. 144-197 and 326-338. 
Marschner, H., 1995. Mineral Nutrition of Higher Plants. $2^{\text {nd }}$ ed. Academic Press. Harcout Brace and Company, Publishers London, San Diego, New York.

Naeem, M., Khan, M.M.A., Idrees, M., Aftab, T., 2010. Phosphorus ameliorates crop productivity, photosynthetic efficiency, nitrogenfixation, activities of the enzymes and content of nutraceuticals of Lablab purpureus L. Scientia Horticulturae, 126: 205-214.

Osman, A.Sh. and El-Sawah, N.A., 2009. Response of tomato plants grown under reclaimed soil conditions to foliar application of magnesium. J. Agric. Sci. Mansoura Univ. 34: 4929-4942.

Page, A.I., Miller, R.H., Keeny, D.R., 1982. Methods of Soil Analysis. Part II. Chemical and Microbiological Methods. $2^{\text {nd }}$ ed. Amer. Soc. Agron., Madison, Wisconsin, USA.

Piper, C.S., 1947. Soil and Plant Analysis. The University of Adelaide, Adelaide, UK.

Rady, M.M., Osman, A.Sh., 2010. Possibility of overcoming the adverse conditions for growth of bean plants in sandy calcareous soil by using bio-phosphorus-fertilizer and Magnesium foliar applications. Egypt. J. Hort. 37: 85-101.

Sabik, F.A., Baza, M.S.M., Monged, N.O., 2001. Effect of biofertilizer and micronutrients applied with different methods on faba bean. Egypt. J. Appl. Sci. 16 (10).

Shafeek, M.R., Abd El-Al, F.S., Ali, A.H., 2004. The productivity of broad bean plants as affected by chemical andlor natural phosphorus with different biofertilizers. J. Agric. Sci., Mansoura Univ. 29: 2727-2740.

Shaheen, A.H., Abdel-Mouty, M.M., Aish, A.M., Rizk, F.A., 2007. Natural and chemical phosphorus fertilizers as affected onion plant growth, bulbs, yield and its some physical and chemical properties. Australian J. Basic and Applied Sci. 1: 519-524.

Snedecor, W.C., Cochran, W.G., 1980. Statistical Methods. $7^{\text {th }}$ ed., lowa state Univ. Press, Ames, lowa, USA.

Wilde, S.A., Corey, R.B., Lyer, J.G., Voigt, G.K., 1985. Soil and Plant Analysis for tree Culture. Oxford and IBM Publishers, New Delhi, India, $3^{\text {rd }}$ ed., pp. 93-106.

Zayed, G., 1998. Can the encapsulation system protect the useful bacteria against their bacteriophages. Plant and Soil, 197: 1-7. 


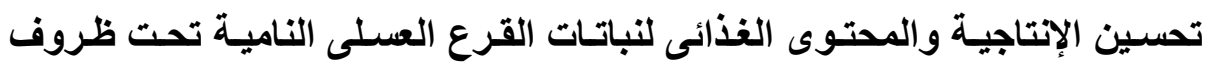

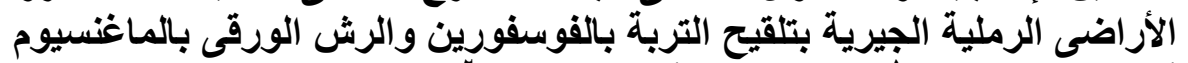

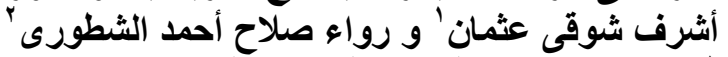

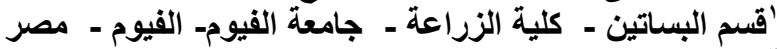

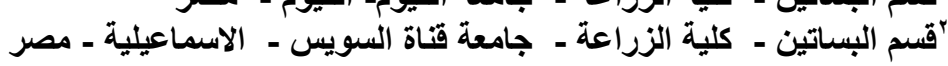

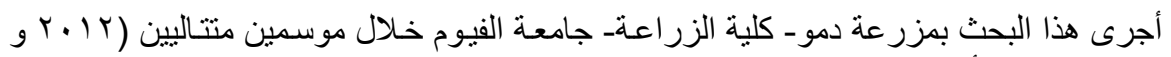

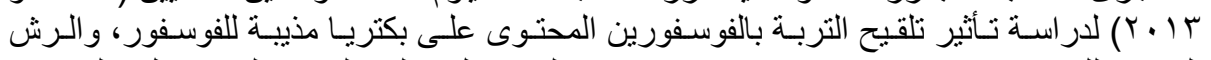

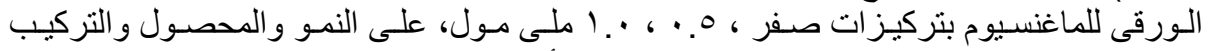

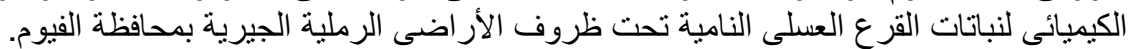

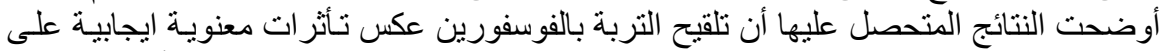

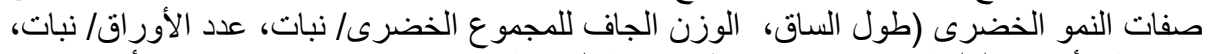

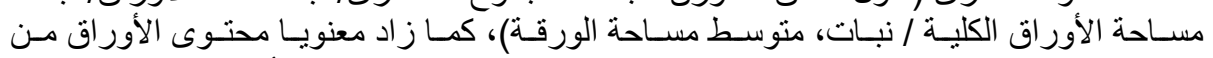

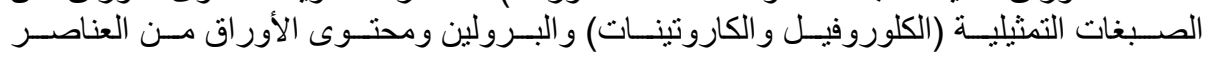

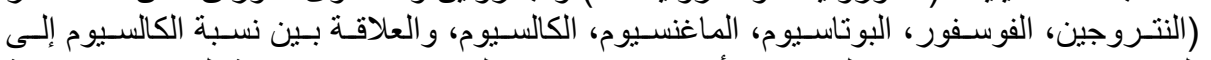

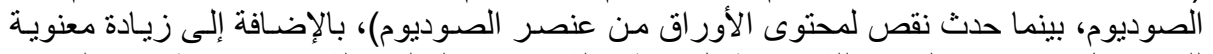

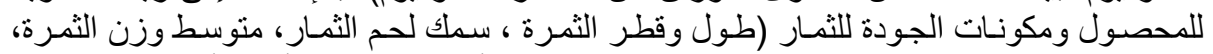

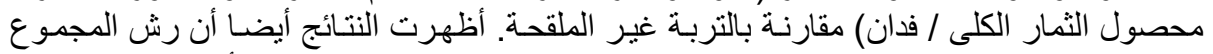

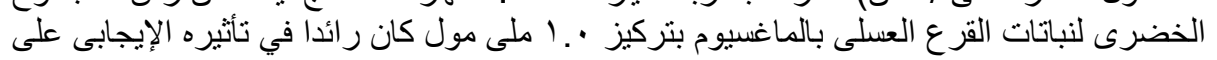
كل الصفات المدروسة والمذكورة العكلى سابقا.

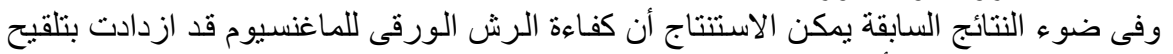

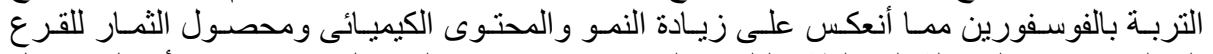

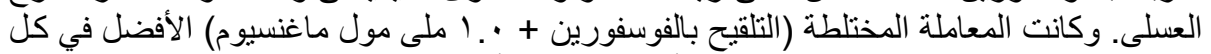

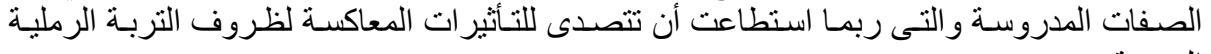
الجيرية. 